\title{
COMPARISON STUDY OF BOD \& COD OF LEACHATE QUALITY (CASE STUDY IN AIR DINGIN LANDFILL AND JATIBARANG LANDFILL)
}

\author{
A.M. Al-Hadi ${ }^{1}$, D.A. Lestari ${ }^{2}$ and J.P. David ${ }^{3}$ \\ Environmental Engineering President University \\ Jl. Ki Hajar Dewantara, Jababeka Education Park, Cikarang, Jawa Barat 17550 \\ 1'aidahmaqbulah01@gmail.com, ${ }^{2}$ dyah.ipa@ gmail.com, ${ }^{3}$ julioputra99@gmail.com
}

\begin{abstract}
Leachate is one of the products that produced by a landfill. Leachate is extremely potential to pollute the environment, such as soil, groundwater and surface water. Air Dingin and Jatibarang landfill have a treatment to treat the leachate produced by the landfill before it is discharged to the environment because it has to be in accordance with Regulation of Ministry of Environment and Forestry of Republic of Indonesia Number P.59/Menlhk/Setjen/Kum.1/7/2016 concern Leachate Standard Quality for Businesses and/or Activities of Landfill. The leachate management in Air Dingin Landfill is controlled landfill, while in Jatibarang landfill, the the leachate management is coagulation-flocculation system. COD and BOD contained in Air Dingin Landfill leachate is lower than Jatibarang Landfill. In order to make leachate more environmental friendly, some innovative methods for leachate management have been developed, such as biofilter, wetlands, coagulationfluctuation, and electrocoagulation.
\end{abstract}

Keywords: (Leachate, Leachate Quality, Leachate Management, Air Dingin Landfill, Jatibarang Landfill).

\begin{abstract}
Abstrak: Air lindi adalah salah satu produk yang dihasilkan oleh TPA. Air lindi sangat berpotensi mencemari lingkungan, seperti tanah, air tanah dan air permukaan. TPA Air Dingin dan TPA Jatibarang memiliki proses pengolahan lindi yang dihasilkan sebelum dibuang ke lingkungan karena harus sesuai dengan Peraturan Menteri Lingkungan Hidup dan Kehutanan Republik Indonesia No. P.59/Menlhk/Setjen/Kum.1/7/2016 tentang Baku Mutu Lindi Bagi Usaha dan/atau Kegiatan Tempat Pemrosesan Akhir Sampah. Metode pengolahan lindi di TPA Air Dingin adalah controlled landfill, sedangkan TPA Jatibarang adalah sistem koagulasi-flokulasi. COD dan BOD yang terkandung di dalam air lindi di TPA Air Dingin lebih rendah daripada TPA Jatibarang. Untuk membuat lindi lebih ramah lingkungan, beberapa metode inovatif untuk pengelolaan lindi telah dikembangkan, seperti biofilter, lahan basah, koagulasi-fluktuasi, dan elektrokoagulasi.
\end{abstract}

Kata Kunci: (Air Lindi, Kualitas Air Lindi, Pengolahan Air Lindi, TPA Air Dingin, TPA Jatibarang).

\section{INTRODUCTION}

Nowadays, landfills in Indonesia become the main problem on the environment of the city. In Indonesia, mostly, landfills only built for disposing of solid waste without noticing the management of the other products that are produced by landfill. Waste in the landfill will produce two products that possibly will pollute the environment, which is biogas and leachate (Mahyudin, 2017).

Leachate has the potential to pollute the environment. It can be a major pollutant in the river, which is the place where the leachate is discharged into. The hazard level of poisoning caused by waste depends on the type and characteristics both in the short and long term (Irhamn et al, 2017). Raghab et al (2013) stated that leachate has the potential to have a high metals concentration and it also has the possibility to contain some hazardous organic chemicals. It also contain pathogenic bacteria (Andesgur et al, 2014). The quality of leachate is very varied and fluctuating depending on a number of things such as the variation and proportion of the components of garbage being dumped, rainfall and season, age of landfill, operational patterns carried out, and sampling time (Malita et al, 2015). Therefore, leachate need to be treated until it can be safe to the environment.

Management of leachate in landfills in Indonesia has not been noticed well by the government, as the apparatus responsible for this. Management of leachate is one of the alternative way to make an integrated 
waste management Leachate water that seeps into the soil can contaminate groundwater, causing soil pollution, groundwater pollution, and surface water pollution. Most landfills in Indonesia currently do not carry out leachate treatment, because they do not have the facilities. Therefore, the quality of the water is still not in accordance with the quality standards. Management of leachate is quite difficult because there are so many things that need to be considered, such as season, type of waste, and age of the landfill (Rezagama et al, 2016).

Ministry of Environment and Forestry of the Republic of Indonesia has stated a regulation concerning on leachate quality standard, which is the Regulation of Ministry of Environment and Forestry of Republic of Indonesia No. P.59/Menlhk/Setjen/Kum.1/7/2016 on Leachate Quality Standard for Business and/or Final Waste Processing Site Activity. All landfill in Indonesia should refer to and comply with that regulation, so the leachate that is produced by a landfill has a standard quality that is stated by the authorized apparatus.

Some researchers found some methods to treat leachate that is produced by landfill. The methods that are researched are biofilter (Said and Hartaja (2015), constructed wetlands (Fajariyah and Mangkoediharjo, 2017), chemical coagulation-flocculation (Rezagama, 2016), and electrocoagulation (Yakobus, 2018). These methods are researched to prevent negative impact to the environment. By using these methods, it is expected that the quality of leachate produced by a landfill can meet the quality standard as stated in the regulation.

\section{MATERIAL AND METHODS}

We took the data from a previous research journal which were from (Sari and Afdal, 2017) and (Rezagama et al, 2016). The specific locations of the research are in Air Dingin Landfill, Baringin Subdistrict, Kota Tangah District, Padang City and in
Jatibarang Landfill, Kedungpane Subdistrict, Mijane District, Semarang City.

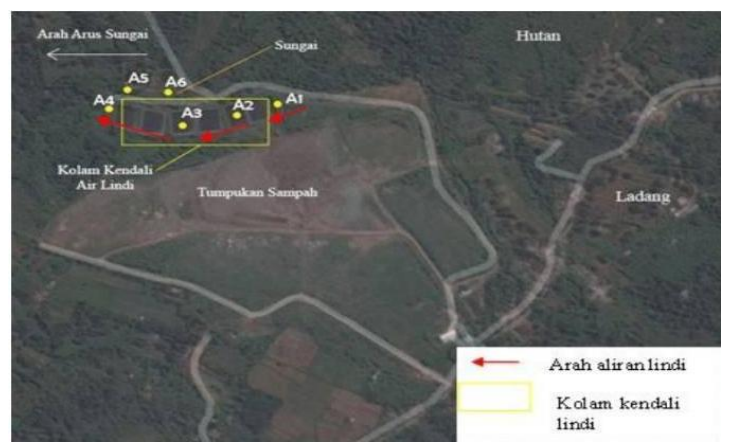

Fig. 1 Air Dingin Landfill Taken from (Sari and Afdal, 2017)

For the data collection of (Sari and Afdal, 2017), they take directly a sample from Air Dingin Landfill. The method that they use to collect data consist of:

1. Measure the $\mathrm{pH}$ value of each samples using a $\mathrm{pH}$ meter

2. Measure the value of electrical conductivity using a conductivity meter

3. Do the TDS test, TDS measurements are carried out by the gravimetry method

4. Then, the TDS value can be determined by:

$$
T D S=\frac{B-C}{V} \times 100 \%
$$

5. Measure the COD and BOD values of leachate in the laboratory, followed by carried out for 6 test samples using the winkler titration method

6. Measure heavy metal content by using Atomic Absorption Spectrophotometry (AAS) in the laboratory (Sari and Afdal, 2017).

From (Rezagama et al, 2016), they take directly a sample from Wastewater treatment Instalasi Pengolahan Limbah (IPL) inlet in Jatibarang Landfill using the grab sampling method in accordance with (SNI 6989.59: 2008). The method that they use to collect data consist of:

1. Experiments using conventional jar-test equipment equipped with 6 glass $1 \mathrm{~L}$ alarms at room temperature 
2. Stirring the samples was carried out in two stages, namely rapid stirring 180 rpm for 2 minutes followed by stirring slowly $40 \mathrm{rpm}$ for 10 minutes. The deposition process lasts for one hour

3. Add coagulants used are $\mathrm{Al}_{2}\left(\mathrm{SO}_{4}\right)$ and $\mathrm{FeCl}_{3}$ with the different dosage

4. Preliminary experiments show doses above $16 \mathrm{~g} / \mathrm{L}$ decrease the efficiency of sediment removal.

In the preliminary test they get a wide range both of these values, where at the addition of $20 \mathrm{~g} / \mathrm{L}$ there is an extraordinary formation of froth aluminum sulfate which affects the process. Some physical chemical parameters tested include TSS, BOD and COD in duplicate (Rezagama et al, 2016).

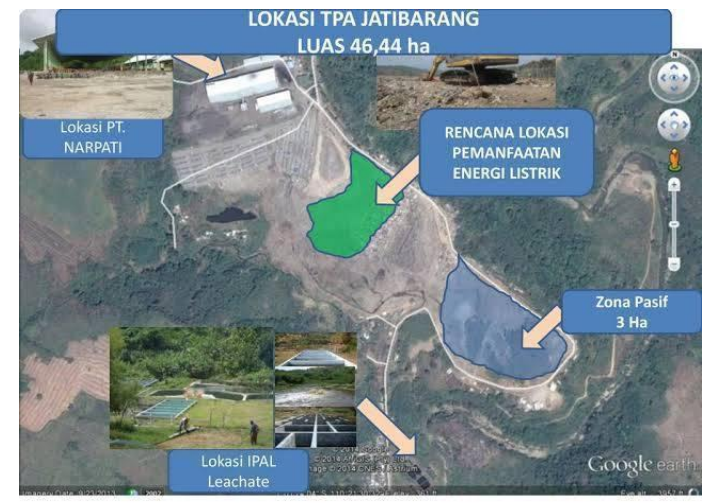

Fig. 2 Jatibarang Landfill

Taken from https://slideplayer.info/slide/12691369/

Leachate-precipitated leachate which has been precipitated is then separated from the water into a smaller glass beaker to make it easier to observe and test characteristics. It also aims to prevent remixing between deposits and the results of coagulation due to current movements sampling (Rezagama et al, 2016).

\section{RESULT and DISCUSSION}

The Temperature of Jatibarang and Air Dingin Landfill

The leachate temperature of Jatibarang landfill is $28.7^{\circ} \mathrm{C}$ and in Air Dingin landfill which is $28.3^{\circ} \mathrm{C}$ (Table 1). It is also known that sunlight has an important role for each leachate in both of landfills. And from government regulation LH P.59/2016 about leachate quality standard the value of temperature which is $38^{\circ} \mathrm{C}$. So, the leachate temperature of Jatibarang and Air Dingin landfill is below threshold Government regulation LH P.59/2016 about leachate quality standard.

Table 1. Comparison of Jatibarang and Air Dingin of leachate characteristic with Leachate Quality Standard

\begin{tabular}{|l|c|c|c|}
\hline Parameter & $\begin{array}{c}\text { Jatibarang } \\
\text { Landfill }\end{array}$ & $\begin{array}{c}\text { Air } \\
\text { Dingin } \\
\text { Landfill }\end{array}$ & $\begin{array}{c}\text { Leachate } \\
\text { Quality } \\
\text { Standard } \\
(*)\end{array}$ \\
\hline $\begin{array}{l}\text { Temperature } \\
\left({ }^{\circ} \mathrm{C}\right)\end{array}$ & 28.7 & 28.3 & $38 *$ \\
\hline $\mathrm{pH}$ & 8.5 & 7.6 & $6-9 *$ \\
\hline $\mathrm{COD}(\mathrm{mg} / \mathrm{L})$ & 4000 & 246.3 & $300^{*}$ \\
\hline BOD (mg/L) & 6000 & 127.1 & $150 *$ \\
\hline
\end{tabular}

*) Government regulation LH P.59/2016 about leachate quality standard

Source : Rezagama, 2016; Sari and Afdal, 2017

\section{pH Value of Jatibarang and Air Dingin Landfill}

$\mathrm{pH}$ of leachate in Air Dingin landfill is 7.6, (table 1), and the $\mathrm{pH}$ of leachate in Jatibarang is 8.5 (table 1). From the government regulation LH P.59/2016 about leachate quality standard the value of $\mathrm{pH}$ which is $6-9$. So, the $\mathrm{pH}$ leachate of Jatibarang and Sumur Dingin landfill is below threshold of Government regulation LH P.59/2016 about leachate quality standard.

\section{COD (mg/L) of Jatibarang and Air Dingin Landfill}

The value of COD leachate in Jatibarang is $4000 \mathrm{mg} / \mathrm{L}$ (table 1), which is higher than Government regulation LH P.59/2016 about leachate quality standard that has maximum COD value of $300 \mathrm{mg} / \mathrm{L}$. Meanwhile, COD value of leachate from Air Dingin landfill is already in 
accordance with the regulation, which is $246.3 \mathrm{mg} / \mathrm{L}$ (table 1).

\section{BOD (mg/L) of Jatibarang and Air Dingin}

The value of BOD leachate in Jatibarang which is $6000 \mathrm{mg} / \mathrm{L}$ (table 1) this value greatly exceeds the threshold from government regulation LH P.59/2016 about leachate quality standard with a value of BOD which is $6000 \mathrm{mg} / \mathrm{L}$. And in Air Dingin landfill has the BOD value which is 127.1 it is mean that still on below from the leachate quality standard of Government regulation LH P.59/2016 about leachate quality standard.

\section{RECOMMENDATION}

To prevent the negative impact of leachate to the environment, there are some recommendation of methods to treat leachate before it is disposed to the environment. These are some methods that can be applied in leachate management.

\section{Biofilter Process}

Biological reactions generally use bacteria that have the ability to decompose pollutants. Biofilter is divided into two process which is aerobic and anaerobic process. Biological system can be are a good choice to treat wastewater, because it is safe, reliable, aesthetic and economic manner (Fuentes and Viscaino, 2018).

\section{a. Aerobic Process}

As the name suggests the process of leachate treatment with aerobic biological processes using oxygen. In this process, aerobic bacteria, organic pollutants, chemical compounds such as sulfides and ammonia will be described in this process so that when leachate is discharged into the environment it will be stable and safe.

As for the reaction that occurs in this aerobic process is (Said and Hartaja, 2015):

Organic pollutant compound $\rightarrow \mathrm{CO}_{2}+$ $\mathrm{HO}_{2}+\mathrm{NH}_{4}+$ Biomass with Oxygen $\left(\mathrm{O}_{2}\right)$ and Heterotropic

As for nitrification correction as follows :

$\mathrm{NH}_{4}++1.5 \mathrm{O}_{2} \rightarrow \mathrm{NO}_{2}^{-}+2 \mathrm{H}++\mathrm{H}_{2} \mathrm{O}$

$\mathrm{NO}_{2}{ }^{-}+0.5 \mathrm{O}_{2} \rightarrow \mathrm{NO}_{3}^{-}$

Sulfur oxidation reaction :

$\mathrm{S}^{2-}+1 / 2 \mathrm{O}_{2}+2 \mathrm{H}+\rightarrow \mathrm{SO}+\mathrm{H}_{2} \mathrm{O}$

$2 \mathrm{~S}+3 \mathrm{O}_{2}+2 \mathrm{H}_{2} \rightarrow 2 \mathrm{H}_{2} \mathrm{SO}_{4}$

For the oxygen that using in this reaction to mix with ammonia and sulfides and other organic the reaction its should equal to oxygen. And organic will be described became biomassa. And biomassa it can be sludge and the next process it is using another process.

\section{b. Anaerobic Process}

In the anaerobic process methane gas is obtained and almost all organic compounds are broken down into a single carbon compound.

during the decomposition stage, an acidification stage occurs which is the decomposition of acidogenic bacteria which hydrates the polymer compounds and converts them to organic acids. While in the next stage the gasification process will convert the results to methane as the final product (Said and Hartaja, 2015).

Organic decomposition reactions that occur in anaerobic processes as follows :

a. Hydrolysis and Acidogenesis

Complex organic pollutants will be hydrolyzed by hydrolase enzymes such as lipase, protease and cellulose. then this monomer will be broken down into fatty acids and hydrogen gas (Said and Hartaja, 2015).

b. The stage of formation of methane gas (methanogenesis)

For the first step to make methane gas which is acetic acid, $\mathrm{H}_{2}$ and $\mathrm{CO}$. And can be also from formic acid and methanol conversion.

$\mathrm{CH}_{3} \mathrm{COOH} \rightarrow \mathrm{CH}_{4}+\mathrm{CO}_{2}$ 
$\mathrm{CO}_{2}+4 \mathrm{H}_{2} \rightarrow \mathrm{CH} 4+\mathrm{H}_{2} \mathrm{O}$

$\mathrm{HCOOH} \rightarrow 0.25 \mathrm{CH}_{4}+0.75 \mathrm{CO}_{2}+0.5$ $\mathrm{H}_{2} \mathrm{O}$

The total of bacteria that using in this process greatly affect the decomposition of the pollutants above (Said and Hartaja, 2015).

\section{Wetlands Process}

Wetland is a process of vegetation which has a role in providing oxygen in the root zone, as a place for attaching bacteria and as an absorbent of pollutants in waste . Plants that can be used in the wetland process is Cyperus papyrus and Canna sp. During this process there will be a decrease in COD value and measurement of BOD, NTK, TP and TSS (Sembiring and Muntalif, 2011).

In the wetlands process, leachate is only put into the wetland and there will be a process inside which is then deposited. as for the duration of deposition depending on how much concentration in the leachate (Sembiring and Muntalif, 2011).

Landfill that has applied this method of leachate treatment is Chunchula Landfill, Mobil County, Alabama. The treatment system surrounds $1.29 \mathrm{Ha}$ of surface-flow wetlands in the boundaries of the landfill. The system is designed to treat leachate and leachate-contaminated groundwater at hydraulic loading rate of $500 \mathrm{~g} / \mathrm{day}$. (Johnson et al, 1999)

\section{Coagulation-flocculation Process}

The coagulation flocculation process utilizes the coagulant properties to reduce the parameters of wastewater. In the coagulation process there will be a process of deposition of particles halu normally using bantual from Earth's gravity so that it becomes a larger particle. While the flocculation process is the process by which suspended particles are stirred slowly to make a larger flock than before. and than is deposited again. after that, there is a process of separation and eliminating pathogenic microorganisms in water. $\mathrm{FeCl} 3$ can be used in this process to increase degradable leachate (Prabowo et al, 2017).

Landfill that has applied this kind of leachate treatment is Hamadan Landfill, Iran. In the study of the method that has been applied, it shows the efficiency of COD removal is $60 \%$ until $70 \%$ and TSS removal is $39 \%$ until 55\% (Samadi et al, 2010).

\section{Electrocoagulation}

Electrocoagulation is a process that uses electrodes to supply ions to the solution, so that contaminants that are emulsified, dissolved and solid form agglomerates (Yakobus, 2017).

There are several stages in this process, which are: Coagulant formation from electrilot oxidation. Furthermore, destabilization of contaminants and particulate suspensions and breakdown of emulsions. and finally aggregation from the destabilization phase to form flocs. Contaminated solutions are handled by chemical reactions and precipitation and attachment of chemicals into the coloid material produced by the electrode. these particles can be separated by sedimentation or the electroflotation then attaches to the $\mathrm{H}_{2}$ bubble changing at the cathode (Yakobus, 2017).

As for the potential series known to be reduced more easily, namely: $\mathrm{K}$. $\mathrm{Ba}, \mathrm{Ca}$, $\mathrm{Na}, \mathrm{Mg}, \mathrm{Zn}, \mathrm{Al}, \mathrm{Cr}, \mathrm{Fe}, \mathrm{Cd}, \mathrm{Co}, \mathrm{Ni}, \mathrm{Sn}$, $\mathrm{Pb}, \mathrm{Sb}, \mathrm{Bi}, \mathrm{Cu}, \mathrm{Hg}, \mathrm{Ag}, \mathrm{Pt}, \mathrm{Au}$. of the many metals, which are very easily oxidized are Al (Yakobus, 2017).

Landfill that has applied electrocoagulation method to treat their leachate is a landfill in Bagalkot Town, India. The method is successfully removed the polluting parameters, such as COD, color, and turbidity with efficiency up to $92.1 \%, 94 \%$ and $95.5 \%$ respectively when the leachate is treated for 35 minutes and 
with DC power supply 9V (Shivayogimath and Watawati, 2014).

\section{CONCLUSION}

Because the treatment of leachate in Air Dingin Landfill and Jatibarang Landfill for the level of BOD, COD, $\mathrm{pH}$, and temperature are still not in accordance with the regulated law. Some researches of leachate treatment, such as biofilter, wetlands, coagulation-fluctuation, and electrocoagulation (as explained in the recommendation) showed that those methods can be a good method to treat leachate. It is highly recommended for all landfill in Indonesia to treat leachate with those methods.

\section{REFERENCE}

Andesgur, I. Hakim, L. Julianto, T. S. 2014. Pengolahan lindi (leachate) dari TPA dengan proses elektrokoagulasi - sedimentasi dan filtrasi. Jurnal Sains dan Teknologi 13(1): 28-34.

Fajariyah, C. Mangkoedihardjo, S. (2017). Kajian Literatur Pengolahan Lindi Tempat Pemrosesan Akhir Sampah dengan Teknik Lahan Basah menggunakan Tumbuhan Air.

Fuentes, N. and Viscaino, L. Y. 2018. Integrated system biodigester biofilter a sustainable option for the environmental management of wastewater from small communities. Contemporary Engineering Sciences 11(87): 4329-4337.

Ganefati, Sri Puji and Susanto, Joko Prayitno. (2015). Pengolahan Lindi (Leachate) Dengan Model Coagulation - Biofilter Anaerobic. Jurusan Kesehatan Lingkungan, Poltekkes Depkes Yogyakarta Peneliti di Pusat Teknologi Lingkungan- BPPT

Irhamni. Pandia, S., Purba, E., and Hasan, W. 2017. Kandungan Logam Berat pada Air Lindi Tempat Pembuangan Akhir (TPA) Sampah Kota Banda Aceh. Tesis. Pascasarjana Unsyiah.

Johnson, K. D., Martin, C. D., Moshiri, G. A., and McCrory, W. C. (1999). Constructed Wetlands for the Treatment od Landfill Leachates Chapter 5. Lewis Publishers, New York.

Malita, Y. A. Ratnawulan. Mufit, F. (2015). Karakterisasi Mineral Magnetik Lindi (Leachate) TPA Air Dingin Kota Padang Menggunakan Scanning Electron Microscopice (SEM). Pillar of Physics 5: 81-88.
Prabowo, Z. N. Rezagama, A. Hadiwidodo, M. 2017. Pengolahan air lindi menggunakan metode koagulasi flokulasi dengan kombinasi biokoagulan sodium alginat - koagulan A12SO4 dan Advanced Oxidation Processes (AOPs) dengan fenton (Fe/H2O2). Jurnal Teknik Lingkungan 6(1): 1-13.

Raghab, S. M. Meguid, A. M. A. E. Hegazi, H. A. 2013. Treatment of leachate from municipal solid waste landfill. HBRC Journal 9: 187-192.

Rezagama, A. (2016). Penyisihan Limbah Organik Air Lindi TPA Jatibarang Menggunakan Koagulasi-Flokulasi Kimia. Teknik 37(2): 78-83.

Said, I. N. and Hartaja, D.R.K (2015) Pengolahan air lindi dengan proses biofilter anaerob-aerob dan denitrifikasi. Pusat Teknologi Lingkungan, BPPT.

Samadi, M.T., Saghi, M. H., Rahmani, A., Hasanvand, J., Rahimi, S., Shirzad, S.M. (2010). Hamadan landfill leachate treatment by coagulation-flocculation process. Iranian Journal of Environmental Health Science and Engineering. 7. 253-258.

Sari, R N. Afdal. (2017) Karakteristik Air Lindi (Leachate) di Tempat Pembuangan Akhir Sampah Air Dingin Kota Padang. Jurnal Fisika Unand 6(1): 93-99.

Sembiring, E. T. J. and Muntalif, B. F. (2011). Optimization of Leachate Treatment Efficiency by Using Constructed Wetland. Jurnal Teknik Lingkungan 17(2): 1-11.

Shivayogimath, C. B. and Watawati, C. (2014). Landfill Leachate Treatment by Electrocoagulation Process Using Iron Sacrificial Electrodes. International Journal of Renewable Energy and Environmental Engineering 2(3).

Yakobus, A. M. (2017). Penanganan Lindi Dari Tempat Pembuangan Air Dengan Proses Elektrokoagulasi. Journal from open access source: zenodo.org 